\title{
THE EFFECTS OF NINE POLLEN DIETS ON BROODREARING OF HONEYBEES
}

\author{
Gerald M. LOPER and Richard L. BERDEL \\ U.S. Department of Agriculture \\ Agricultural Research \\ Science and Education Administration \\ Carl Hayden Bee Research Center \\ 2000 East Allen Road \\ Tucson, Arizona, 85719
}

\begin{abstract}
SUMMARY
Pollens were evaluated with a bioassay that measures the relative nutritional efficiency of diets of young honeybees (Apis mellifera L.) rearing brood from eggs to the sealed cell stage of larval development. Relative nutritional efficiency was determined by calculation of the number of sealed cells produced per gram of diet consumed per bee per day. Saguaro (Cereus giganteus) pollen was used as the standard against which other pollens were tested. The bioassay results of pollens collected in 1977 showed that a diet of saguaro was more efficient than diets of cottonwood (Populus deltoides), but not of almond (Prunus dulcis). Bioassays of the pollens collected in 1978 showed that saguaro was more efficient than london rocket mustard (Sisymbrium irio) but not bladderpod mustard (Lesquerella gordoni). No brood was raised on a diet of dandelion pollen (Taraxacum officinale) or of dandelion fortified with L-arginine.
\end{abstract}

\section{INTRODUCTION}

Many pollens have been chemically analyzed by TODD and BRETHERICK (1942), VIVINO and PALMER (1944), LUNDÉN (1954), and others. Wide variations in amounts of nutrients in pollens available to honeybees (Apis mellifera L.), have been demonstrated, but little is known regarding the ability of different pollens to stimulate bees to feed larvae. WAHL (1963) reported increased sealed cell production by honeybees fed summer crucifer or fruit pollen mixed with honey. However, they obtained lower production from hazel pollen, even lower production from dandelion, and no effect from the pollens of spruce and pine. Herbert et al. (1970) showed that 
honeybees were unable to rear brood when fed pure dandelion pollen in varying percentages up to $50 \%$ (by wgt.) mixed with sugar. CAMPANA and Moeller (1977) reported that when bees were fed blackberry, willow, sweet clover, boxelder, fruit bloom and mixed pollen diets, the most bees were reared by those fed sweet clover; however, in terms of nutritional efficiency, bees fed fruit bloom, boxelder and mixed pollen diets sealed the most cells per gram of diet consumed.

We tested nine pollen diets for broodrearing capability using a bioassay that measures the ability of young bees to rear brood from eggs to the sealed cell stage of larval development (LOPER and BERDEL, 1980).

\section{MATERIALS AND METHODS}

\section{Pollen Collection and Preparation}

Diets were prepared from bee-collected pollen, hand sorted by color and then microscopically identified. All pollens were trapped from the bees using O.A.C. (SMITH and ADIE, 1963) type traps and then frozen until used, but no consistent collection schedule was followed. When sorted and identified, pollens were $95 \%+$ pure. The crude protein content of the pollens was estimated by the Kjeldahl nitrogen method.

Test pollens collected in 1977 were saguaro (Cereus giganteus), almond (Prunus dulcis), and cottonwood (Populus deltoides); in 1978 saguaro, almond, dandelion (Taraxacum officinale), bladderpod mustard (Lesquerella gordoni) and london rocket mustard (Sisymbrium irio) were collected.

Preliminary tests showed maximum $(P<.05)$ production of sealed cells when saguaro diet was fed with $30 \%$ sucrose compared to $15 \%$ or $60 \%$; therefore, all diets reported were formulated with $30 \%$ of their dry weight as sucrose. The only exception was the dandelion-arginine diet (formulated according to HeRBerT et al., 1970), which contained $90 \%$ (dry wgt.) powdered sugar and $48 \mathrm{mg} \mathrm{L}$-arginine per $100 \mathrm{gm}$ protein. To achieve even distribution of $2.5 \mathrm{mg}$ arginine in $377 \mathrm{gm}$ diet, $3.4 \mathrm{mg}$ arginine monohydrochloride was dissolved in $1 \mathrm{ml}$ water and mixed with the diet for $10 \mathrm{~min}$. Distilled water was added to the diets to achieve the consistency required to form pellets. Water content of the diets was $16 \pm 4.8 \%$.

Diet pellets were made by pressing diet into a circle $5.5 \mathrm{~cm}$ diameter $\times 1 \mathrm{~cm}$ thick, with a Teflon ${ }^{R}$ plunger and cylinder adapted to a small drill press. This reduced variation in consistency and surface area that might have affected consumption. To allow for removal and addition of diet with little disturbance to bees in nucs (wood boxes $.26 \times .13 \times .20 \mathrm{~m}$, with screened bottoms), a piece of screen was embedded in the diet pellet and copper wire pushed through and twisted to secure the pellet. A tag to record weight and diet type was secured to the other end of the wire.

\section{Bioassay Conditions}

The tests reported in this paper took place in July through November of 1978 . The test procedures were repeated at four-week intervals. Incubation room temperature was $30.6 \pm 0 .{ }^{\circ} \mathrm{C}$ and $\%$ relative humidity was $63 \pm 13$. Newly emerged bees were counted and brushed from frames directly into nucs in a rotating manner to distribute the bees from colonies to each nuc. Nucs were then placed in a completely randomized design in individual, screened cages $\left(0.93 \mathrm{~m}^{3}\right)$ for the initial feeding and maturation

1. Mention of a trademark, proprietary product or vendor does not constitute a guarantee or warranty by the U.S.D.A. and does not imply its approval to the exclusion of other products or vendors that may also be suitable. 
period. Nucs contained two $20 \mathrm{gm}$ pellets of the test diet flanked on both sides by $15 \times 8 \mathrm{~cm}$ sheets of wax comb foundation to provide bees easy access to the diet; two empty petri dishes were placed above the diet and beneath the feeding bottles to receive occasional dripping liquid. Inverted bottles (50 ml) with three holes $(0.68 \mathrm{~mm})$ drilled in each cap provided ad libitum access to $60 \%$ (total solids) sucrose solution and distilled water. Previous tests showed this hole size was critical to ad libitum feeding because bees stored no sugar syrup when smaller $(0.53 \mathrm{~mm})$ holes were provided and bottles leaked when larger $(1.57 \mathrm{~mm})$ holes were used. Bee access to bottles was through screen-covered holes in the nuc top. Water and sugar syrup were added when necessary. Diet, sucrose and water controls were added to a nuc without bees to measure weight and volume changes not caused by bee consumption.

\section{Brood-rearing}

On the tenth day after newly emerged bees were brushed into the nuc, the sealed cell test was started. Bees were chilled by reducing room temperature to about $20^{\circ} \mathrm{C}$ to force clustering. Old diet was removed, weighed and replaced with two $10 \mathrm{gm}$ diet pellets of the same diet; sugar syrup and water bottles were refilled. A frame of eggs was put in each nuc with two virgin queens and the test starting time of the tests were recorded when all nucs were fed. Tests were conducted in a room $(6.0 \times 3.0 \times 2.4 \mathrm{M})$ with controlled temperature $\left(29.6 \pm 0.7^{\circ} \mathrm{C}\right)$ and $\%$ relative humidity $(68 \pm 6)$. Light was provided by sixteen 40 watt full-spectrum fluorescent lamps $(21.4 \pm 1.0 \mathrm{lux})$ automatically switched on at $1800 \mathrm{hr}$ and off at $0600 \mathrm{hr}$. Two 60 watt red lights were on continuously during the test for observations during dark periods.

\section{Calculations}

Ten days after frames of eggs were put in the nucs, the tests were terminated. The bees were gassed, frozen and counted, the sealed cells were counted, and unconsumed diet, sugar syrup and water were measured. An index (Brood Rearing Efficiency Index = BREI) was devised to provide a comparison of results that removes variations between tests created by unequal numbers of nurse bees and length of test. The BREI is calculated by dividing the number of sealed cells reared in each nuc by the mean number of bees ( live bees at start + live bees at finish/2), and by the number of test days, and the grams of diet consumed, and then multiplying by $10^{9}$ to get a whole number. Use of the BREI should permit comparisons of results from other scientists using this same or very similar tests. It should be noted however, that nearly the same number of bees and length of test would have to be used in order to make valid comparisons using the BREI.

In addition, overall nitrogen conversion efficiency (conversion of dietary nitrogen to larval nitrogen) was calculated by using the literature value of $3.2 \mathrm{mg} N$ required to rear one bee (HAYDAK, 1935).

Because of possible seasonal variation in quantity and viability of bee eggs, each test was analyzed individually to determine which results were significantly different from those with the standard saguaro diet. WAHL (1963) reported that broodrearing was significantly influenced by weather and season even when the bees were fed a constant diet.

Data were first treated by analyses of variance and $F$ tests for a completely randomized design. Data were further analyzed by Duncan's multiple range tests and by regression analyses (LITTLE and Hills, 1972).

\section{RESULTS AND DISCUSSION}

Bee flight cages provided space for cleansing flights and removal of debris from nucs, thus reducing possible stresses imposed by our earlier test procedures. Bees 
were seen flying in most cages during the $1800-0600 \mathrm{hr}$ light period, but they stayed inside the nucs during the $0600-1800 \mathrm{hr}$ dark period of red light illumination.

The pollens varied from 15.0 to 43.0 percent protein (Tabl. 1). When formulated into diets, protein content varied from 1.4 to 24.0 percent.

\section{Test Number 1}

In July, saguaro diet was tested against almond and cottonwood diets. The nutritional efficiency of saguaro and almond was found to be greater $(P<.01)$ than that of cottonwood (Tabl. 2). Diet consumption also showed significant $(P<.01)$ differences; bees fed saguaro ate more than those fed almond. Also, more $(P<.01)$ protein was consumed when bees ate saguaro and almond than when they ate cottonwood. These results agree with the review of STANLEY and LiNSKENS (1974) that Populus pollen is a poor pollen for feeding bees. It is worth noting that even though protein in saguaro was only 2.2 percentage points more than that in cottonwood, 100 percent more sealed cells were produced per saguaro-fed bee (Tabl. 2).

\section{Test Number 2}

Differences in nutritional efficiency were significant $(P<.01)$ in the September test, which demonstrated that saguaro and almond pollens produced more sealed cells per diet consumed than dandelion pollen (Tabl. 2). Diet consumption per bee did not vary significantly among the treatments; however, more $(P<.01)$ protein was consumed with almond pollen than with saguaro, and more protein was consumed with saguaro pollen than with dandelion.

MAURizio (1954) reported that dandelion pollen stimulated the development of brood-food (hypopharyngeal) glands and STANDIFER (1966) reported that dandelion pollen was highly attractive to honeybees. Our results (Tabl. 2), however, indicated no production of sealed cells by five nucs of bees fed dandelion pollen ( $9.9 \%$ protein), which agreed with the results of WAHL (1963) and HERBERT et al. (1970).

\section{Test Number 3}

The results of the nutritional efficiency test of October demonstrated that saguaro diet was superior $(P<.05)$ to london rocket even though significantly $(P<.01)$ more protein was consumed by bees eating london rocket than by those eating saguaro or bladderpod diet (Tabl. 2). 


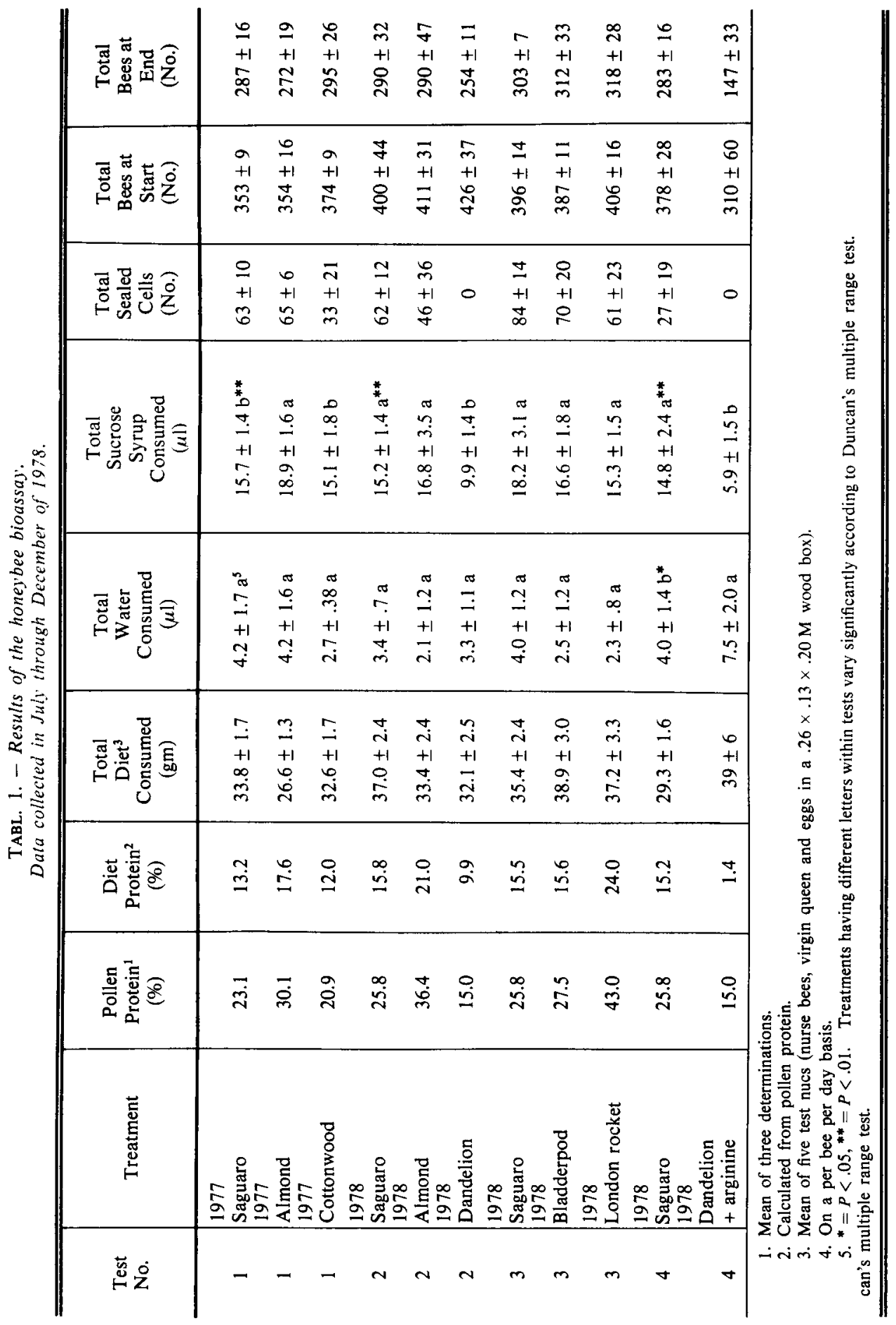




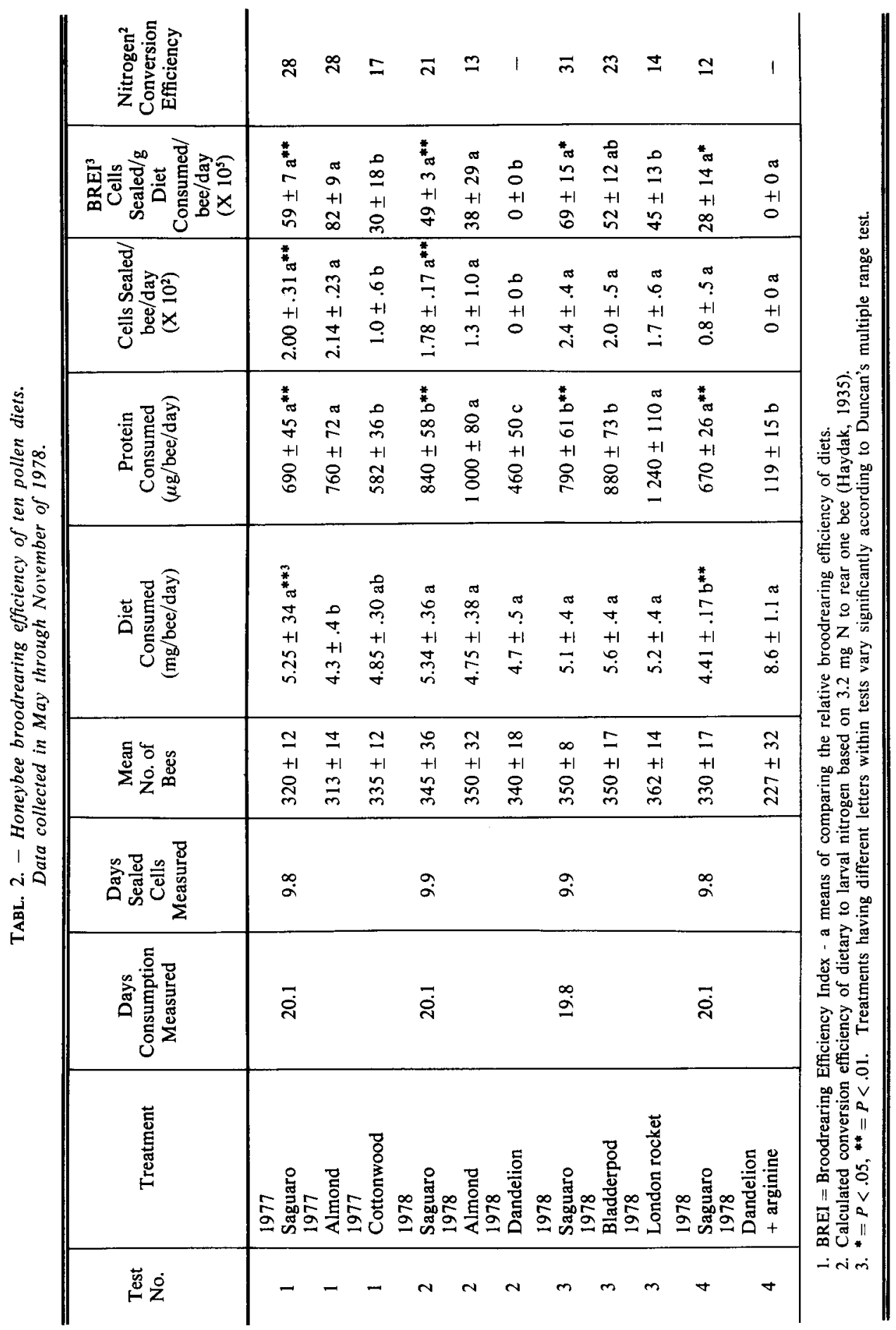


Test Number 4

In the November test, we tried a diet reported by HERBERT et al. (1970) composed of $10 \%$ dandelion pollen fortified with sucrose and L-arginine. The arginine-fortified dandelion diet did not support broodrearing (Tabl. 2). This result is contrary to the report of HERBERT et al. (1970). They reported complete broodrearing for 3 generations when the dandelion + arginine diet was fed under different test conditions. The lack of brood-rearing in our dandelion + arginine test may have been influenced by poor egg viability at that particular season because the sealed cells on the standard saguaro diet were also low*.

\section{Comparisons and Correlations}

Regression analysis of food consumption demonstrated significant $(P<.001)$ coefficient $(r)$ values for each data group. Water consumption was correlated negatively with sucrose syrup and protein $(r=.47, r=.52$ at $53 \mathrm{df})$, but positively with diet consumption ( $r=.70$ at $53 \mathrm{df}$ ). Sucrose syrup consumption correlated positively with protein but negatively with diet consumption $(r=.62, r=.62$ at $53 \mathrm{df})$.

Sealed cell production correlated positively $(P<.05)$ with water and sucrose consumption $(r=.36, r=.32$ at $43 \mathrm{df}$ ) but the observed $r$ values for protein and diet $(r=.240, r=.253$ at $43 \mathrm{df}$ ) were not quite high enough (required $r=.255$ at $58 \mathrm{df}$, $P<.05)$ to be considered significantly correlated with sealed cells. This indicated that production of sealed cells was influenced significantly by a diet parameter(s) not measured.

We believe the BREI data most clearly expresses the relative nutritional efficiency of a diet to support broodrearing. Calculations based on diet consumption produced significant differences not seen when calculations were based on protein consumption.

On the basis of sealed cells per diet consumed, test results showed that, of the pollens collected in 1977, saguaro was used more efficiently $(P<.01)$ than cottonwood but not more efficiently than almond. Of the pollens collected in 1978, saguaro was used more efficiently than dandelion $(P<.01)$, london rocket $(P<.05)$ and dandelion + arginine $(P<.05)$, but saguaro was not used more efficiently than almond or bladderpod mustard. This information could be useful to beekeepers collecting or buying pollens. Results of the saguaro and london rocket test confirmed our 1977 observations that a diet high in protein is not necessarily the best diet for brood-rearing (HERBERT $e t$ al., 1977). Perhaps the best measure of the bioassay procedure as well as another comparison of diet nutritional value is the nitrogen conversion efficiency data (Tabl. 2). The best conversion in this series of tests was $31 \%$ with the saguaro diet.

* Subsequent tests (1979) have confirmed that no broodrearing occurs in our tests by bees fed dandelion or dandelion + arginine diets. 
Comparisons within tests are more valid than between tests. Future use of this bioassay may be able to gauge the results by equalling or, hopefully, improving nitrogen conversion efficiencies. More refined studies using this bioassay should quickly elucidate the various nutritional requirements of honeybees for good brood production. In particular, further studies are needed to attempt to resolve the differences in experimental results using dandelion pollen fortified with arginine.

\section{ACKNOWLEDGMENTS}

We thank Joseph WAGNER and Lynus Richards for Kjeldahl analyses of pollens, Robert SCHMAL= ZEL for microscopic identification and purity analyses of pollens, Tom MARTIN, A.J. NACHBAUER, Jr. and Gordon D. Waller for bee-collected pollens and Steve Alejandro, Linda GilberT and Cyra Kane for technical support.

Received for publication in July 1980.

\section{RÉSUMÉ}

INFLUENCE DE NEUF REGIMES DE POLLEN SUR L'ÉLEVAGE DU COUVAIN PAR LES ABEILLES

Cet article présente les données sur la valeur nutritive relative (pour l'élevage du couvain) de pollens communs dans le désert du Sud-Ouest américain. Durant notre test de 10 jours, on a mesuré la production de cellules operculées dans des petits nuclei. Le test a nécessité à chaque fois $60 \mathrm{mg}$ de pollen récolté par les abeilles et environ 380 nourrices récemment écloses.

Pour chaque test on a comparé deux pollens avec celui de saguaro (Cereus giganteus) pris comme témoin et on a répété cinq fois l'essai pour chaque pollen. Les résultats obtenus sur la période de juillet à novembre ont montré que les pollens testés semblaient réagir différemment du témoin, peut-être en raison des variations saisonnières dans la viabilité de l'œuf et/ou du passage des abeilles d'été aux abeilles d'hiver. Pour une cause quelconque le nombre de cellules avec larve ayant atteint le stade operculé a chutć dramatiquement en novembre.

En général nos résultats ont permis de classer les pollens en trois catégories nutritives qui correspondent avec les résultats de MAURIzIo (1954) et de WAHL (1963). Le saguaro, l'amandier (Prunus dulcis) et Lesquerella gordoni ont conduit tous trois également au plus grand élevage de couvain. Les pollens de peuplier (Populus deltoides) de Sisymbrium irio ont permis un élevage moyen de couvain et le pissenlit (Taraxacum officinale) n'a permis aucun élevage de couvain. Nous n'avons pas réussi à améliorer l'élevage du couvain sur le pissenlit en ajoutant de l'L-arginine comme le firent HerberT et al. (1970). Ainsi le pollen de pissenlit s'est révélé être un pollen de valeur nutritive très basse dans des régions géographiques très variées et dans différents tests.

\section{ZUSAMMENFASSUNG}

DIE WIRKUNG DER FÜTTERUNG MIT NEUN VERSCHIEDENEN POLLENSORTEN AUF DIE BRUTTÄTIGKEIT VON HONIGBIENEN

Diese Arbeit bringt Ergebnisse über den relativen Nährwert (bezogen auf die Bruttätigkeit) von Pollensorten, die in der Wüstenzone der südwestlichen U.S.A. häufig vorkommen. Es wurde ein Biotest 
über 10 Tage benutzt, bei dem die Produktion von verdeckelten Brutzellen in kleinen Kernvölkern gemessen wurde. Für den Versuch wurden $60 \mathrm{~g}$ Höschenpollen und etwa 380 frisch geschlüpfte Pflegebienen je Ansatz benötigt. Bei jedem Versuch wurden 2 Pollensorten mit dem Pollen des Säulenkaktus (Saguaro, Cereus giganteus) als Standard verglichen, wobei für jeden Pollen 5 Wiederholungen angesetzt wurden.

Die Ergebnisse aus der ganzen Saison von Juli bis September sprechen dafür, dass es unterschiedliche Reaktionen auf den Standardpollen gibt, möglicherweise als Folge von verschiedener Überlebensrate der Eier und (oder) Unterschiede zwischen Sommer- und Winterbienen. Im November sank aus unbekannten Gründen die Zahl der Zellen mit Larven, die bis zum Stadium der Verdeckelung gelangten, dramatisch ab.

Im allgemeinen können die Pollensorten auf Grund unserer Versuche nach ihrem Nährwert in drei Kategorien geteilt werden, die mit den Ergebnissen von Maurizıo (1954) und WAHL (1963) übereinstimmen. Saguaro, Mandel (Prunus dulcis) und Blasenschoten-Senf (Lesquerella gordoni) führten gleichermassen zu der höchsten Bruttätigkeit. Pollen der Pappel (Populus deltoides) und Glanzrauke (Sisymbrium irio) veranlassten eine nur mässige Bruttätigkeit und Löwenzahn (Taraxacum officinale) gar keine. Es ist uns nicht gelungen, die Brutaufzucht bei Löwenzahn-Futter durch Zugabe von L-Arginin zu verbessern, so wie dies HeRBerT et al. (1970) getan haben. Damit wurde nachgewiesen, dass Löwenzahnpollen in weit auseinanderliegenden geographischen Gebieten und in verschiedenen Versuchen ein Pollen von sehr geringem Nährwert ist.

\section{REFERENCES}

Campana B. J., Moeller F. E., 1977. - Honeybees : preference for and nutritive value of pollen from five plant sources. J. Econ. Entomol, 70, 39-41.

HAGEDoRN H. H., Burger M., 1968. - Effect of the age of pollen used in pollen supplements on their nutritive value for the honeybee. II. Effect of vitamin content of pollens. J. Apic. Res. 7,97-101.

HaYdaK M. H., 1935. - Answer to a disputed question. Glean. Bee Cult. 63, 211.

Herbert E. W., Bickley W. E., Shimanuki H., 1970. - The broodrearing capability of caged honeybees fed dandelion and mixed pollen diets. J. Econ. Entomol. 63, 215-218.

Herbert E. W., JR., Shimanuki H., Caron D., 1977. - Optimum protein levels required by honeybees (Hymenoptera : Apidae) to initiate and maintain broodrearing. Apidologie. 8, 141-146.

LitTle T. M., Hills F. J., 1972. - Statistical Methods in Agricultural Research. Univ. of Calif., Davis, Calif. 95616.

LOPER G. M., BERDEL R. L., 1980. - A nutritional bioassay of honeybee broodrearing potential. Apidologie, 11, 181-189.

LUNDÉN K., 1954. - A short introduction to the literature on pollen chemistry. Svensk Kem. Tidskr. 66, 201-213.

Maurizio A., 1954. - Pollen nutrition and life processes of the honeybee. Landwirt. Jahrb. Schweiz. 68, 115-182.

NIELSON N., GRÖMMER J., LUNDÉN R., 1955. - Investigation on the chemical composition of pollen from some plants. Acta. Chem. Scand. 9, 110n-1106.

Smith M. V., Adie A., 1963. - The O.A.C. pollen trap. Can. Bee J. 74, 4-5, 8.

STANDIFER L. N., 1966. - Fatty acids in dandelion pollen gathered by honeybees. Ann. Ent. Soc. Am. 59, 1005-1008.

Stanley R. G., Linskens H. F., 1974. - Chap. 7 in Pollen: biology, biochemistry, management. Springer-Verlag.

Todd F. E., Bretherick O., 1942. - The composition of pollens. J. Econ. Entomol. 35, 312-317.

Vivino A. E., Palmer L. S., 1944. - The chemical composition and nutritional value of pollens collected by bees. Archives of Biochemistry. 4, 129-136.

WAHL O., 1963. - Comparative investigations on the nutritive value of pollen, yeast, soy flour and powdered milk for the honeybee. Z. Bienenforschung. 6, 209-280. 